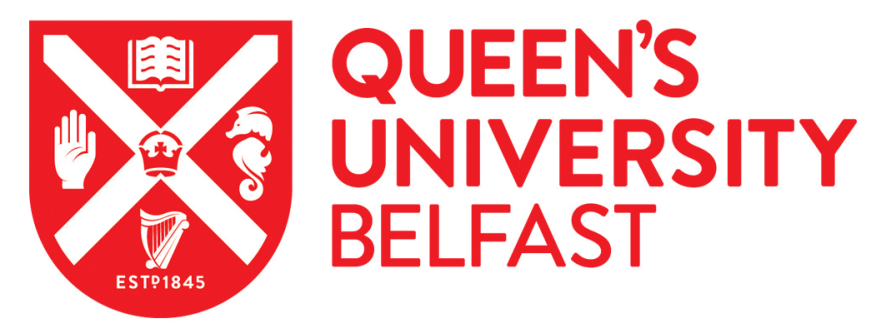

\title{
Kunitzins: Prototypes of a new class of protease inhibitor from the skin secretions of European and Asian frogs
}

Chen, X., Wang, H., Chen, Y., Wang, L., Zhou, M., Chen, T., \& Shaw, C. (2016). Kunitzins: Prototypes of a new class of protease inhibitor from the skin secretions of European and Asian frogs. Biochemical and Biophysical Research Communications, 477(2), 302-9. https://doi.org/10.1016/j.bbrc.2016.06.062

Published in:

Biochemical and Biophysical Research Communications

Document Version:

Peer reviewed version

Queen's University Belfast - Research Portal:

Link to publication record in Queen's University Belfast Research Portal

Publisher rights

(c) 2016 Elsevier Inc. All rights reserved.

This is an open access article published under a Creative Commons Attribution-NonCommercial-NoDerivs License

(https://creativecommons.org/licenses/by-nc-nd/4.0/), which permits distribution and reproduction for non-commercial purposes, provided the author and source are cited.

(C) Elsevier 2016

\section{General rights}

Copyright for the publications made accessible via the Queen's University Belfast Research Portal is retained by the author(s) and / or other copyright owners and it is a condition of accessing these publications that users recognise and abide by the legal requirements associated with these rights.

Take down policy

The Research Portal is Queen's institutional repository that provides access to Queen's research output. Every effort has been made to ensure that content in the Research Portal does not infringe any person's rights, or applicable UK laws. If you discover content in the

Research Portal that you believe breaches copyright or violates any law, please contact openaccess@qub.ac.uk. 


\section{Kunitzins:prototypes of a new class of protease inhibitor from the skin secretions of}

\section{European and Asian frogs}

Xiaole Chen ${ }^{1, *}$, He Wang ${ }^{2, *}$, Yue Shen ${ }^{3}$, Lei Wang ${ }^{3}$, Mei Zhou ${ }^{3}$, Tianbao Chen ${ }^{3}$, Chris Shaw ${ }^{3}$

1. School of Pharmacy, Fujian Medical University, Fuzhou, Fujian, China

2. School of Integrative Medicine, Fujian University of Traditional Chinese Medicine, Fuzhou, 350001, Fujian, China

3. MedicineNatural peptide discovery group, School of Pharmacy, Queen's University, Belfast BT9 7BL, Northern Ireland, UK

* Corresponding author.

E-mail address: leochen5139@fjmu.edu.cn (Xiaole Chen); hwang11@qub.ac.uk (He Wang) 


\section{Abstract}

Amphibian skin secretions contain biologically-active compounds, such as antimicrobial peptides and trypsin inhibitors, which are used by biomedical researchers as a source of potential novel drug leads or pharmacological agents. Here, we report the application of a recently developed technique within our laboratory to "shotgun" clone the cDNAs encoding two novel but structurally-related peptides from the lyophilized skin secretions of one species of European frog, Rana esculentaand one species of Chinese frog, Odorranaschmackeri. Bioanalysis of the peptides established the structure of a 17-mer with an N-terminal Ala (A) residue and a C-terminal Cys (C) residue with a single disulphide bridge between Cys 12 and 17, which is a canonical Kunitz-type protease inhibitor motif (CKAAFC-). Due to the presence of this structural attribute, these peptides were named kunitzin-RE (AAKIILNPKFRCKAAFC) and kunitzin-OS (AVNIPFKVHLRCKAAFC). Synthetic replicates of these two novel peptides were found to display a potent inhibitory activity against Escherichia coli but were ineffective at inhibiting the growth of Staphylococcus aureus and Candida albicans at concentrations up to $160 \mu \mathrm{M}$ and both showed little haemolytic activity at concentrations up to $120 \mu \mathrm{M}$. Subsequently, kunitzin-RE and kunitzin-OSwere found to be a potent inhibitor of trypsin with a $\mathrm{Ki}$ of $5.56 \mu \mathrm{M}$ and $7.56 \mu \mathrm{M}$ that represent prototypes of a novel class of highly-attenuated amphibian skin protease inhibitor. Substitution of Lys-13, the predicted residue occupying the P1 position within the inhibitory loop, with Phe (F) resulted in decrease in trypsin inhibitor effectiveness and antimicrobial activity against Esherichia coli, but exhibits a potential inhibition activity against chymotrysin.

Key words: Amphibian; Venom; inhibitor; Peptide; Cloning; Antimicrobial 


\section{Introduction}

Frogs have survived successfully over millions of years without detectable changes in their morphology. Their first-line of defence against predators and pathogens appears to be reliant on the synthesis and secretion of a complex array of bioactive molecules from highlyspecialised dermal granular or poison glands that also appear to represent a primitive innate immune system ${ }^{[1-2]}$. As modern analytical and mass spectrometric technologies develop, more novel peptides are being identified in and isolated from these complex amphibian defensive skin secretions. Meanwhile many peptides, which have hitherto been considered to be unique in one species, have been found to be widely-distributed in many structurally-related forms across different species. Scientists are also interested in studying different bioactivities among the newly discovered compounds secreted from frogs. The majority of these compounds are related to the amphibian defence system, such as antimicrobial peptides, neurotoxins, antioxidants and protease inhibitors ${ }^{[1-4]}$.

Protease inhibitors (PIs), widely found in animals, microorganisms and plants, are known to play key roles in the aetiology and treatment of human pathologies such as cancer, inflammation and haemorrhage, based on their inhibiting the catalytic activity of proteolytic enzymes $^{[5]}$. In addition, PIs appear to be a class of drugs representing a vital source of lead compounds for the treating or preventing of infection by viruses or pathogens, including HIV and Hepatitis $\mathrm{C}$, in accordance with their capability of inhibiting the extracellular proteases which are believed to be widely produced by many pathogens (Christeller 2005). Thus PIs are useful tools to study and ultimately to better understand the functional principles of protein actives leading to the design of highly-specific drugs to control pathologic processes (Dockray et al 1975, Sampaio et al 1996, Goraya et al 1998).

Protease inhibitors are widely-distributed in amphibian skin secretions. Kunitz inhibitors have been found in the skin secretions of bombinid toads and ranid frogs, Kazal inhibitors in 
phyllomedusine frogs and Bowman-Birk inhibitors in ranid frogs. Kunitz protease inhibitors usually contain four Cys residues that form two disulphide bridges and a single reactive centre as canonical structural features of the group [4,](Conlon et al 2009, Sampaio et al 1996, Goraya et al 1998). Furthermore, Kunitz-type inhibitors containing the rare signal peptide disulphide bridges have been isolated from frog skin secretions and this new type of trypsin inhibitor is apparently widely present in these secretions such that it can provide a wide spectrum of action templates for designing specific inhibitors for discrete protease targets (Lambert et al 2004).

In this study, we report the identification, structural characterisation, and cloning of skin-derived cDNAs that encode novel peptides with antimicrobial and potent trypsin inhibitory activities. Bioinformatic analysis indicated that both peptides contain a canonical Kunitz-type reactive centre and hence represent the smallest natural members of this established inhibitor family discovered to date. As a consequence of their structural and functional attributes, the peptides were named kunitzin-RE and kunitzin-OS. As the donor species (the European Edible frog, Rana esculenta, and the Chinese frog, Odorranaschmackeri), effectively represent the extremes of the range of Eurasian ranid frogs, it would not be unreasonable to suggest that kunitzins are of widespread occurrence in other species and this broad distribution may be reflective of an important if not fundamental role in the defence of the frogs. Meanwhile, the protease inhibitory potency of synthetic P1substituted analogues (Phe ${ }^{13}$-kunitzins) and the catalytic loops were also synthesised and evaluated by comparing that of wild-typekunitzins for structure-activity relationship in this study. 


\section{Materials and methods}

\section{Preparation of skin secretion}

Rana esculenta ( $n=4,4-6 \mathrm{~cm}$ snout to vent length) were obtained from a local herpetological supplierandOdorranaschmackeri( $\mathrm{n}=3$, respectively) were captured during expeditions in the People's Republic of China. All frogs were adults and secretion harvesting was performed in the field after which frogs were released. Skin secretions were obtained from the dorsal skin using gentle transdermal electrical stimulation as previously described. The stimulated secretions were washed from the skin using deionised water and divided into either $0.2 \% \mathrm{v} / \mathrm{v}$ aqueous trifluoroacetic acid (for subsequent peptide characterisation), or into cell lysis/mRNA stabilisation buffer (Dynal) for subsequent cDNA library construction.

\section{"Shotgun" cloning of skin secretion-derived cDNA}

Five mg samples from each lyophilised skin secretion were separately dissolved in $1 \mathrm{ml}$ of cell lysis/mRNA protection buffer supplied by DynalBiotec, UK. Polyadenylated mRNA was isolated by the use of magnetic oligo-dT beads as described by the manufacturer (DynalBiotec, UK). The isolated mRNA was subjected to 3'-rapid amplification of cDNA ends (RACE) procedures to obtain full-length antimicrobial peptide precursor nucleic acid sequence data using a SMART-RACE kit (Clontech, UK) essentially as previously described. Briefly, the 3'-RACE reactions employed a nested universal primer (NUP), supplied with the kit, and a degenerate sense primer (5'-GTTCACCATGAAGAAATCCCTGTTACT-3') that was designed to a highly conserved domain of the 5'-untranslated region of previously characterised antimicrobial/trypsin inhibitor peptide cDNAs from Rana species. The 3'RACE reactions were purified and cloned using a pGEM-T vector system (Promega Corporation) and sequenced using an ABI 3730 automated sequencer. 


\section{Identification and structural analysis of novel precursor cDNA encoded peptides}

Five mg samples from each lyophilised skin secretion were dissolved separately in $0.5 \mathrm{ml}$ of $0.05 / 99.95(\mathrm{v} / \mathrm{v})$ trifluoroacetic acid (TFA)/water and clarified of microparticulates by centrifugation. The supernatants were then separately subjected to reverse phase HPLC fractionation using a Cecil Adept Binary HPLC system (Adept Technology, Inc. USA) fitted with an analytical column (Phenomenex C-5; $0.46 \mathrm{~cm} \times 25 \mathrm{~cm}$ ). This was eluted with a linear gradient formed from $0.05 / 99.5 \quad(\mathrm{v} / \mathrm{v})$ TFA/water to $0.05 / 19.95 / 80.0 \quad(\mathrm{v} / \mathrm{v} / \mathrm{v})$ TFA/water/acetonitrile in $240 \mathrm{~min}$ at a flow rate of $1 \mathrm{ml} / \mathrm{min}$. Fractions $(1 \mathrm{ml})$ were collected and the effluent absorbance was continuously monitored at $\lambda=214 \mathrm{~nm}$. Samples $(100 \mu \mathrm{l})$ were removed from each fraction in triplicate, lyophilised and stored at $-20^{\circ} \mathrm{C}$ prior to bioactivity assays. The fractions that exhibited specified activity were subjected to MALDI-TOF MS analysis using a Perseptive Biosystems Voyager DE instrument (Framingham, MA, USA) in positive ion mode and $\alpha$-cyano-4-hydroxycinnamic acid as matrix. Internal mass calibration of the instrument with peptide standards established the accuracy of mass determinations as $\pm 0.01 \%$. Subsequently, each of the novel peptideswere chemically synthesised using solidphase Fmoc methodology on a PS3 automated peptide synthesiser (Protein Technologies Inc., AZ, USA). Products were purified and structures confirmed by LC/MS/MS.

\section{Synthesis of kunitzins, the analogues (Phe ${ }^{13}$-kunitzins) and catalytic loops}

Following unequivocal establishment of the primary structure of natural kunitzin-RE and kunitzin-OS, replicates were synthesised by solid-phase Fmoc chemistry using a PS3 automated peptide synthesiser (Protein Technologies, Tucson, AZ, USA). When the synthesis cycles were completed, the peptides were cleaved from the resins using 95/2.5/2.5 (v/v/v) TFA/TIPS/water for $6 \mathrm{~h}$, precipitated in ether over the next $24 \mathrm{~h}$, washed exhaustively in six changes of ether and then allowed to completely dry over a further $24 \mathrm{~h}$. The peptides were then dissolved in a minimal quantity of $0.05 / 99.5, \mathrm{v} / \mathrm{v}, \mathrm{TFA} / \mathrm{water}$, snap frozen in liquid 
nitrogen and lyophilised. Degree of purity and authentication of structures of the synthetic peptides were determined using MALDI-TOF MS as previously described. The analogues (Phe ${ }^{13}$-kunitzins) and the catalytic loops of both wild-type and analogue peptides were also synthesised using the same method.

\section{Antimicrobial assays}

Antimicrobial activities of synthetic kunitzins and their analogues were assessed by determination of minimal inhibitory concentrations (MICs) using a standard Gram-positive bacterium S. aureus-NCTC 10788), a standard Gram-negative bacterium (Escherichia coli-NCTC 10418) and a standard pathogenic yeast (Candida albicans NCPF 1467). kunitzin-RE and kunitzin-OS were tested within the concentration range of $160-2.5 \mu \mathrm{M}$ and were initially dissolved as a stock solution of $200 \mu \mathrm{M}$ in sodium phosphate-buffered saline, $\mathrm{pH}$ 7.2, and subsequently diluted in Mueller-Hinton broth (MHB). Peptide concentrations in the range stated, were inoculated with microorganism cultures (105 colony forming units $(\mathrm{CFU}) / \mathrm{ml})$, and placed into 96-well microtiter cell culture plates. Plates were incubated for 18 $\mathrm{h}$ at $37^{\circ} \mathrm{C}$ in a humidified atmosphere. Following this, the growth of bacteria/yeast was determined by means of measuring optical density (OD) at $\lambda=550 \mathrm{~nm}$ by an ELISA plate reader (BioliseBioTek EL808). Minimal inhibitory concentrations (MICs) were defined as the lowest concentration at which no growth was detectable.

\section{Hemolysis assay}

A $2 \%$ suspension of red blood cells was prepared from defibrinated horse blood (TCS Biosciences Ltd, UK). Kunitzin-RE and kunitzin-OS solutions of different concentrations were prepared as described in a previous section. Two hundred microlitres of the red blood cell suspension were incubated with a range of kunitzin-RE and kunitzin-OS concentrations similar to those employed for antimicrobial assays at $37^{\circ} \mathrm{C}$ for $2 \mathrm{~h}$. Lysis of red cells was assessed by measurement of optical density at $\lambda=550 \mathrm{~nm}$ using an ELISA plate reader 
(BioliseBioTek EL808). Negative controls employed consisted of a 2\% red cell suspension and sodium phosphate-buffered saline in equal volume and positive controls consisted of a $2 \%$ red cell suspension and an equal volume of sodium phosphate-buffered saline containing $2 \%$ of the non-ionic detergent, Triton X-100 (Sigma-Aldrich). The percent haemolysis was calculated using the following equation: \%haemolysis= $(\mathrm{A}-\mathrm{A} 0) /(\mathrm{AX}-\mathrm{A} 0) \times 100$ where 'A' is absorbance at ive controls employed consisted of a $2 \%$ red cell ce at $\lambda=550 \mathrm{~nm}$ with phosphate-buffered saline and ' $\mathrm{AX}$ ' is absorbance at $\lambda=550 \mathrm{~nm}$ with $2 \%$ Triton $\mathrm{X}-100$.

\section{Trypsin inhibition assay.}

Trypsin $(10 \mu \mathrm{l}$ of a $0.1 \mu \mathrm{M}$ stock solution in $1 \mathrm{mMHCl})$ was added to the wells of a microtitre plate containing substrate (Phe-Pro-Arg-NHMec, obtained from Sigma/Aldrich, Poole, Dorset, UK) $(50 \mu \mathrm{M})$ and either reconstituted chromatographic fraction (33\%), in the first instance or, subsequently, synthetic peptide replicates $(10-1000 \mu \mathrm{M})$ in $10 \mathrm{mM}$ phosphate buffer, $\mathrm{pH} 7.4$, containing $2.7 \mathrm{mMKCl}$ and $137 \mathrm{mMNaCl}$ (final volume $210 \mu \mathrm{l}$ ). Each determination was carried out in triplicate. The rate of hydrolysis of substrate was monitored continuously at $37^{\circ} \mathrm{C}$, by measuring the rate of increase of fluorescence due to production of 7-amino-4-methylcoumarin $\left(\mathrm{NH}_{2} \mathrm{Mec}\right)$ at $460 \mathrm{~nm}$ (excitation $360 \mathrm{~nm}$ ) in a FluoStar OPTIMA plate reader (BMG LABTECH, Germany)

\section{Chymotrypsin inhibition assay.}

Inhibitory activity assays on synthetic peptide replicates and their various P1-sitesubstituted variants against chymotrypsin, were performed exactly as detailed for the trypsin inhibition assay, except that the target protease was chymotrypsin and the fluorogenic substrate utilised was Succinyl-Ala-Ala-Pro-Phe-NHMec (obtained from Bachem, UK).

\section{Trypsin cleavage of inhibitor peptides}

$1 \mathrm{mg}$ of trypsin (Sigma) and 1mg each of synthetic novel inhibitor peptides were separately incubated in $1 \mathrm{ml}$ of sodium phosphate buffer, $\mathrm{pH} 7.2$, at room temperature $\left(25^{\circ} \mathrm{C}\right)$ 
for $2 \mathrm{~h}$. Samples $(20 \mu \mathrm{l})$ were removed at $10 \mathrm{~min}$ intervals into $100 \mu \mathrm{l}$ of $0.05 \%(\mathrm{v} / \mathrm{v})$ trifluoroacetic acid/water to terminate reactions. One microlitre of each was placed in separate wells of a MALDI-TOF sample plate, mixed with $1 \mu$ of matrix solution ( $\alpha$-cyano-4hydroxycinnamic acid in 50/50 (v/v) water/acetonitrile), air dried and subjected to analysis on a Perseptive Biosystems DE MALDI-TOF instrument.

\section{Result}

"Shotgun" cloning of novel peptide-encoding cDNAs

The full-length kunitzin-RE and kunitzin-OS biosynthetic precursorencodingcDNAswere separately and repeatedly cloned from the $R$. esculentaand $O$. schmackeri skin secretion cDNA libraries and each encoded a single copy of respective putative mature peptides (Figure1). The NCBI BLAST search found that the novel peptides from $R$. esculenta and $O$. schmackeri showed at least $88 \%$ sequence identity, respectively, with Ranaturerin-2Ra and $2 \mathrm{R}$ from $R$. ridibunda (Figure $2 \mathrm{~A}$ ). In terms of the novel peptide precursor protein architectures, the $\mathrm{N}$-terminal 22 amino acid residues encode a putative signal peptide and the following 29 amino acids constitute the acidic amino acid residue-rich spacer peptide domain that contains two classical-Lys-Arg- (-K-R-) propeptide convertase cleavage sites, the latter of which immediately flanks the N-terminus of the putative mature peptides. Both mature peptide sequences consisted of a 17-mer with an N-terminal Ala (A) residue and a C-terminal Cys (C) residue with a single disulphide bridge between Cys 12 and 17. The nucleotide sequences of the precursor-encoding cDNA of kunitzin-RE and kunitzinOS havebeen deposited in Genbank Nucleotide Sequence Database under the accession code CCG00970 and AMW87025.

Isolation and structural characterisation of kunitzin-RE and kunitzin-OS from reverse phase HPLC fractions of skin secretion 
Following prediction of the molecular masses ofkunitzin-RE and kunitzin-OS from the cloned precursors and compensation for post-translational modification (single disulphide bridge formation in the $\mathrm{C}$-terminal loop $=-2 \mathrm{amu}$ ), each mature peptide was identified in skin secretion HPLC fractions from respective species (Figure3andTable 1). Synthetic replicates of both novel peptides were successfully synthesised and obtained with a high degree of purity in the first attempt by the methodology employed and the molecular masses of the purified products were confirmed to be identical to those of the natural peptides by use of MALDI-TOF mass spectrometry analysis. The primary structures of kunitzin-RE and kunitzin-OS were determined by MS/MS fragmentation sequencing (Figure4) unambiguously. Antimicrobial/haemolytic activities of synthetic kunitzin-RE, kunitzin-OS and their analogues

Both the natural novel peptides and their synthetic replicates possessed relatively potent growth inhibitory activity against the Gram-negative bacterium, E. coli (Table2), with MICs of $30 \mu \mathrm{M}$ and $20 \mu \mathrm{M}$, respectively, but were ineffective against the Gram-positive bacterium, S. aureus and the pathogenic yeast, $C$. albicans at concentrations up to $160 \mu \mathrm{M}$. Both peptides possessed little haemolytic activity at concentrations up to and including $120 \mu \mathrm{M}$.

\section{Trypsin inhibition and peptide cleavage}

Wide-type peptides and their synthetic replicates, kunitzin-RE and kunitzin-OS were found to possess relatively potent inhibitory activity against trypsin with $K i$ values of 5.56 $\mu \mathrm{M}$ and $7.56 \mu \mathrm{M}$, respectively. A synthetic replicate of the cyclic C-terminal six-residue loop (-CKAAFC-) possessed no apparent trypsin-inhibitory activity.

Synthetic peptides with the natural Lys-13 residue occupying the P1 position within the inhibitory loop were the most potent trypsin inhibitors with no chymotrypsin activity even when employed at a concentration of $1 \mathrm{mM}$. However, when Lys-13 was replaced by Phe (F), trypsin inhibitory activity was completely abolished and a modest inhibitory activity towards 
chymotrypsin was observed. The resultant 'Morrison plots' (Table 3) derived from these latter progress curves, yielded $K i$ values of $17.5 \mu \mathrm{M}$ and $67.98 \mu \mathrm{M}$ for chymotrypsin inhibition by both site-substituted analogues, respectively.

The synthetic replicates of both novel natural peptides were cleaved by trypsin. The data obtained from these experiments are summarised in Table 4 and demonstrate that the cleavage fragments are generated through cleavage of classical trypsin sensitive sites. On the basis of these data, we presume that both inhibitor peptides act in a substrate-like manner and that they may compete with the synthetic trypsin-substrate for the active site of the enzyme.

\section{Discussion}

Various types of compounds synthesised and/or stored in frog skin, including amines, alkaloids and peptides, form a fundamental part of their anti-predator defence systems. In response to stress, compression of the peptide-containing serous cells is initiated and these host-defence peptides, stored in the granular glands, are secreted by a holocrine-like mechanism onto the dorsal surface [2](Bode et al 1992, McPhee et al 2005, Otvos 2005). Serine protease inhibitors are one of the most studied groups of natural biomolecules as they play key roles in controlling blood coagulation and inflammation as well as a large number of other essential life processes. In Nature, protein-based protease inhibitors protect the host against a range of extrinsic proteases produced by invading microorganisms (Tamechika et al 1996) and these inhibitors can be generally classified according to the presence of a defined structural motif as Kunitz, Kazal or Bowman- Birk (Zasloff 1987). The Bowman-Birk-like trypsin inhibitor from the skinsecretion of Huia versabilis (HV-BBI), exhibits a potent inhibition against trypsin ${ }^{[4]}$. The Kunitz-type trypsin inhibitor isolated from the skin secretion of Dyscophusguineti, a species which apparently does not produce classical antimicrobial peptides, is proposed to play a role as an anti-infective agent (Zasloff 2002). 
In the present study, two novel peptides, each containing 17 amino acid residues, have been identified from two different species of frog representing two continents, Europe and Asia, and both contain six-residue C-terminal disulphide-bridged loops (-CKAAFC-), formed by two cysteine residues. This conserved six-residue loop is suggestive of an antimicrobial function for these novel peptides as the ranatuerin-2 family of frog skin antimicrobial peptides display a C-terminal cyclic hexapeptide domain rather than the more common heptapeptde of others (Otvos 2005, Zasloff 2002). However, while the ranatuerin-2 family of peptides first identified in the bullfrog, Lithobates catesbeianus (Pukala et al 2006), have a marked variation in their amino acid sequences and some members, for example, the potent broad-spectrum antimicrobial peptide ranatuerin-2CSa isolated from the Cascades frog, Rana cascadae (Pukala et al 2006), have been proposed as templates for antibacterial drug development, the two novel peptides discovered here display no structural similarity with ranatuerins and only limited antimicrobial activity against the Gram-negative bacterium, $E$. coli, are hence not members of this family. Thus the analogues previously identified in the skin secretion of Rana ridibunda, have been named erroneously.

Further biological investigations on the two novel peptides found both to be rather potent inhibitors of trypsin with $K i$ values of approximately 5.56 and $7.56 \mu \mathrm{M}$, for the Rana esculenta (RE) and Odorrana schmackeri (OS) peptides, respectively. Bioinformatic analysis of the primary structures of the two novel peptides established that they exhibited structural similarity to the "so-called" Rana ridibunda ranatuerins - a nomenclature that is erronoeous as discussed previously, and to a series of trivially named antimiocrobial peptides from several species of Chinese frogs, most notably from the ranid genus, Amolops, all of which are unpublished observations. These data however, imply that the peptides described in this study, are of widespread occurrence in the skins of a considerable number of species from a variety of ranid frog taxa of both European and especially of Asian origin. Such widespread 
expression and conservation of peptide structure across taxa is often indicative of a fundamental biological role.

Bioinformatic analysis of the primary structure of the novel peptides indicated that the C-terminal disulphide-bridged loop exhibited a high degree of identity with the inhibitory loops of several Kunitz-type protease inhibitors from a variety of sources (Figure 2B), all of which possess either a Lys $(\mathrm{K})$ or an $\operatorname{Arg}(\mathrm{R})$ residue in the P1 site. This residue confers specificity for trypsin and proteases that cleave with a trypsin-like claeavage site specificity following a basic amino acid residue. For this reason and for the potent trypsin inhibitory activity displayed by both peptides, we named these peptide kunitzins as prototypes of a novel class of protease inhibitor from amphibian skin secretions.

The $\mathrm{P} 1$ site is occupied by a Lys (K) residue in the conserved kunitzin motif, -CKAAFC, and synthetic analogues of both peptides incorporating a Phe (F) residue in this position (CFAAFC-), displayed little inhibitory activity against trypsin even completely losing this ability, although they then exhibited a modest inhibitory activity against chymotrypsin. Thus, from the limited structure/activity data presented here, a Lys residue has apparently been selected by Nature to occupy this site within the six-residue loop and direct the inhibitory activity of the kunitzin towards a protease or proteases with trypsin-like cleavage specificity. Once the basic Lys residue in this P1 position is replaced by an aromatic amino acid residue (F), such analogues lose trypsin inhibitory activity and at the same time, their antimicrobial activity in addition. These data have also supplied evidence that the cyclic six-residue loop (CKAAFC), has no inhibitory activity against trypsin in its own right and must require other features of the primary structure of the peptides to achieve this.

An observation of interest was that both kunitzins were catabolised by trypsin and identification of the catabolites of each peptide using MS showed that tryptic cleavages involved were classical. We presume that these fragments may play some roles in the other 
biological processes or that they may serve to imply that kunitzins act as pseudo-substrates and that this represents their mode of inhibitory action. Of interest was the fact that the Cterminal loop structure was not identified until late in respective incubations which would imply that this highly-ordered structure was maintained in the reactive center of the trypsin until cleaved after the Lys residue. The incremental increase in molecular mass of 18 amu observed for this fragment in late incubation would be consistent with hydrolysis of the Lys$\mathrm{X}$ bond but with retention of the catabolite as a loop structure.

The complex cocktail of compounds stored in the glandular glands of frogs consist of at least one broad-spectrum antibiotic peptide together with a number of other narrow-spectrum activity peptides which act against one or several kinds of bacteria. These narrow-spectrum antibacterial peptides can not only supply enhanced protection against a range of bacteria, but also have other roles in the defence system. An example of this are the caerins 2.1 , isolated from Litoria splendida. These are narrow-spectrum antibiotic peptides against some Gramnegative organisms but also inhibit the production of nitric oxide by neuronal nitric oxide synthase (Otvos 2005).

There are a number of principles used to explain the membrane permeation or lytic mechanisms that lead to the death of microorganisms. The most important one is the fundamental structural principle known as amphipathic design. The peptides, containing clusters of hydrophobic and cationic amino acids, are able to adopt a shape to bind the membrane bilayer leading to cell lysis. These processes are thought to disturb the membrane or induce 'wormhole' formation so that the peptides can be transported into the inner leaflet and then produce defined pores, causing death of the target cell. Such kinds of peptides are usually linear and possess an $\alpha$-helical secondary structure but most Rana frog peptides have instead modified C-terminal sequences with a single disulphide loop using a rigid anti- 
parallel $\beta$-sheet as the framework (Otvos 2005, Qi et al 2005a, Qi et al 2005b, Song et al 2008).

As a type of Kunitz trypsin inhibitor, kunitzins also exhibit a narrow-spectrum antibacterial activity against the Gram-negative bacterium, Escherichia coli. These unusual peptides may be transported into the inner bacterial membrane to disrupt multiple cellular processes or additionally target a trypsin-like protease inside the Gram-negative bacteria resulting in their death. However the antibacterial mechanisms are still unclear and require further investigation.

\section{Acknowledge}

This work was supported by National Natural Science Foundation, China (Grant No. 81402842), Natural Science Foundation of Fujian Province, China (Grant No. 2015J05162), Natural Science Foundation of Fujian Province, China (Grant No. 2016J01374), Fujian Provincial outstanding talents for Education and Scientific research (Grant No. JK2014016) and The doctor startup foundation of Fujian Medical University (Grant No.2012bs002).

\section{Conflict of Interest statement}

The authors declare that they have no conflict of interest.

\section{Ethical statement}

All applicable international, national, and/or institutional guidelines for the care and use of animals were followed. 


\section{Data deposition footnotes}

The nucleotide sequences of the kunitzin-RE and kunitzin-OS precursors have been deposited

in the Genbank Nucleotide Sequence Database under the accession code CCG00970 and AMW87025. 


\section{References}

Christeller, J. T. (2005). REVIEW ARTICLE: Evolutionary mechanisms acting on proteinase inhibitor variability. The FEBS Journal, 272, 22, 5710-5722.

Dockray, G. J., \& Hopkins, C. R. (1975).Caerulein Secretion by Dermal Glands in Xenopuslaevis. The Journal of Cell Biology, 64, 3, 724-733.

Sampaio, C. A., Oliva, M. L., Sampaio, M. U., Batista, I. F., Bueno, N. R., Tanaka, A. S., Auerswald, E. A., Fritz, H. (1996).Plant serine proteinase inhibitors.Structure and biochemical applications on plasma kallikrein and related enzymes.Immunopharmacology, 32, 1-3.

Goraya, J., Knoop, F., \& Conlon, J. (1998).Ranatuerins: Antimicrobial Peptides Isolated from the Skin of the American Bullfrog, Rana catesbeiana. Biochemical and Biophysical Research Communications, 250, 3, 589.

Lambert, E., Dassé, E., Haye, B., \&Petitfrère, E. (2004).TIMPs as multifacial proteins.Critical Reviews in Oncology, 49, 3, 187-98.

Lingaraju, M. H., \& Gowda, L. R. (2008). A Kunitz trypsin inhibitor of Entadascandensseeds: another member with single disulfide bridge. BiochimicaEtBiophysicaActa, 1784, 5, $850-5$.

McPhee, J. B., \& Hancock, R. E. (2005). Function and therapeutic potential of host defence peptides. Journal of Peptide Science, 11, 11, 677-87.

Otvos, L. J. (2005). Antibacterial peptides and proteins with multiple cellular targets.Journal of Peptide Science, 11, 11, 697-706.

Pukala, T. L., Bowie, J. H., Maselli, V. M., Musgrave, I. F., \& Tyler, M. J. (2006). Hostdefence peptides from the glandular secretions of amphibians: structure and activity. Natural Product Reports, 23, 3, 368-93. 
Qi, R. F., Song, Z. W., \& Chi, C. W. (2005).Structural features and molecular evolution of Bowman-Birk protease inhibitors and their potential application.ActaBiochimicaEtBiophysicaSinica, 37, 5, 283-92.

QI, R.-F., SONG, Z.-W., \& CHI, C.-W.(2005). Structural Features and Molecular Evolution of Bowman-Birk Protease Inhibitors and Their Potential Application.ActaBiochimicaEtBiophysicaSinica, 37, 5, 283-292.

Song, G., Zhou, M., Chen, W., Chen, T., Walker, B., \& Shaw, C. (2008). HV-BBI--A novel amphibian skin Bowman-Birk-like trypsin inhibitor. Biochemical and Biophysical Research Communications, 372, 1, 191.

Tamechika, I., Itakura, M., Saruta, Y., Furukawa, M., Kato, A., Tachibana, S., \& Hirose, S. (1996).Accelerated evolution in inhibitor domains of porcine elafin family members.The Journal of Biological Chemistry, 271, 12, 7012-8.

Zasloff, M. (1987).Magainins, a Class of Antimicrobial Peptides from XenopusSkin: Isolation, Characterization of Two Active Forms, and Partial cDNA Sequence of a Precursor. Proceedings of the National Academy of Sciences of the United States of America, 84, $15,5449-5453$.

Zasloff, M. (2002).Antimicrobial peptides of multicellular organisms.Nature, 415, 6870, 38995.

Zhang, R., Zhou, M., Wang, L., McGrath, S., Chen, T., Chen, X., \& Shaw, C. (2010). Phylloseptin-1 (PSN-1) from Phyllomedusasauvagei skin secretion: A novel broadspectrum antimicrobial peptide with antibiofilm activity. Molecular Immunology, 47, 2030-2037. 


\section{Legends to Figures}

Figure 1.Nucleotide and translated open-reading frame amino acid sequences of cloned cDNAS encoding the biosynthetic precursors of (A) kunitzin-RE and (B) kunitzin-OS. Putative signal peptides are double-underlined, mature peptides are single-underlined and the respective stop codons are indicated by asterisks.

Figure 2.(A)The primary structures of the novel kunitzin peptides from $R$. esculentaand $O$. schmackeri skin secretion compared with Ranatuerin-2Ra and $2 \mathrm{R}$ from $R$. ridibunda, respectively. Fully conserved residues are indicated with asterisks. Please note that bioinformatic analysis has indicated that the $R$. ridibundaranatuerin peptides are NOT structurally-related to canonical ranatuerins. (B)Comparison of the reactive centre of kunitzins with those from other selected Kunitz-type protease inhibitors. BPTI=Bovine pancreatic trypsin inhibitor; APPI=Amyloid protein precursor inhibitor; $\mathrm{AAPH}=\mathrm{Amyloid}$ precursor protein homologue; TFPI=Tissue factor pathway inhibitor; HA1=Hepatocyte growth factor activator inhibitor; PLI=Porcine leukocyte inhibitor; UPTI=Uterine plasmin/trypsin inhibitor; SPI=Silk proteinase inhibitor; AsKC=Anemoniasulcatakalicludine .

Figure 3.Region of reverse phase HPLC chromatograms of the skin scretions of Rana esculenta (A) and Odorrana schmackeri (B) with arrows indicating elution/ retention times kunitzin-RE and kunitzin-OS, respectively. The Y-axis indicates absorbance units at $\lambda=214 \mathrm{~nm}$.

Figure 4. Predicted b- and y-ion MS/MS fragment ion series (singly- and doubly- charged) of kunitzin-RE (A) and kunizin-OS (B). Observed ions are indicated in bold typeface. 


\section{Legends to Tables}

Table 1Molecular masses and primary structures of Kunitzin-RE and Kunitzin-OS identified in semi-preparative reverse phase HPLC fractions of $R$. esculenta and $O$. schmackeriskin secretion, respectively. The calculated (calc) and observed (obs) masses are monoisotopic. $\mathrm{Mr}$ (obs) values are deduced from the protonated molecules.

Table 2Inhibitor constants for 'wide-type'kunitzin-RE and -OS and their respective P1 sitesubstituted variants against trypsin and chymotrypsin.

Table 3Minimum inhibitory concentrations $(\mu \mathrm{M})$ of synthetic replicates of kunitzin-OS and kunitzin-RE and their P1 site-substituted variants, against reference strains of microorganisms used in this study.

Table 4 Catabolites generated by incubation of Kunitzin-RE and Kunizin-OS with trypsin.Computed molecular masses of kunitzin tryptic catabolites compared to those detected by MALDI-TOF MS. 
Figure 1

(A)

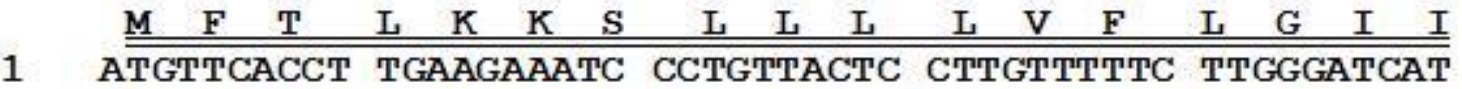
TACAAGTGGA ACTTCTTTAG GGACAATGAG GAACAAAAAG AACCCTAGTA $\begin{array}{lllllllllllllllll}\mathrm{S} & \mathrm{L} & \mathrm{S} & \mathrm{L} & \mathrm{C} & \mathrm{K} & \mathrm{Q} & \mathrm{E} & \mathrm{R} & \mathrm{D} & \mathrm{A} & \mathrm{N} & \mathrm{E} & \mathrm{E} & \mathrm{R} & \mathrm{R}\end{array}$

51 CTCCTTATCT CTCTGTAAAC AAGAGAGAGA TGCCAATGAA GAGAGAAGAG GAGGAATAGA GAGACATTTG TTCTCTCTCT ACGGTTACTT CTCTCTTCTC

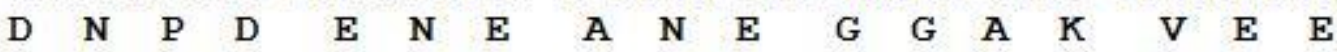

101 ATAATCCAGA TGAAAATGAA GCAAATGAGG GGGGAGCTAA AGTGGAAGAA TATTAGGTCT ACTTTTACTT CGTTTACTCC CCCCTCGATT TCACCTTCTT

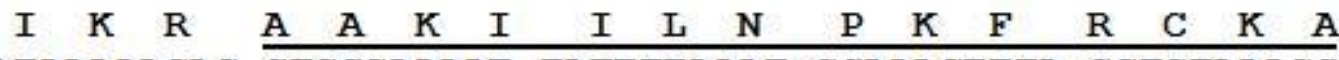

151 ATAAAAAGAG CTGCGAAAAT TATTTTAAAT CCAAAGTTTA GGTGTAAAGC TATTTTTCTC GACGCTTTTA ATAAAATTTA GGTTTCAAAT CCACATTTCG

$201 \frac{\text { A }}{\text { TGCATTCTGT TAAAACTGGA ATTGGAAGCT AATTGCTAAA TGTCTAAATT }}$ ACGTAAGACA ATTTTGACCT TAACCTTCGA TTAACGATTT ACAGATTTAA

251 ATTTAGCTAA ATAATAATAA AAATTTCACA TACACTAAAA AAAAAAAAAA TAAATCGATT TATTATTATT TTTAAAGTGT ATGTGATTTT TTTTTTTTTT

301 AAAAAAAAAA AAAAAA TTTTTTTTTT TTTTTT

(B)

1

\begin{tabular}{ccccccccccccccccr} 
M & F & T & L & K & K & S & L & L & L & L & F & F & L & G & F & I \\
\hline \hline ATGTTCACCT & TGAAGAAATC & CCTGTTACTC & CTTTTCTTTC & TTGGGTTCAT
\end{tabular} TACAAGTGGA ACTTCTTTAG GGACAATGAG GAAAAGAAAG AACCCAAGTA $\begin{array}{llllllllllllllll}\mathrm{S} & \mathrm{L} & \mathrm{S} & \mathrm{L} & \mathrm{C} & \mathrm{E} & \mathrm{E} & \mathrm{E} & \mathrm{R} & \mathrm{D} & \mathrm{A} & \mathrm{N} & \mathrm{E} & \mathrm{E} & \mathrm{R} & \mathrm{R}\end{array}$

51 CTCCTTATCT CTCTGTGAGG AAGAGAGAGA TGCCAATGAA GAAAGAAGAG GAGGAATAGA GAGACACTCC TTCTCTCTCT ACGGTTACTT CTTTCTTCTC $\begin{array}{lllllllllllllllll}\text { D } & D & \text { P } & \text { D } & \text { E } & \text { S } & E & \text { A } & \text { N } & E & G & E & A & K & V & E & E\end{array}$

101 ATGATCCAGA TGAAAGTGAA GCAAATGAGG GGGAAGCTAA AGTGGAAGAA TACTAGGTCT ACTTTCACTT CGTTTACTCC CCCTTCGATT TCACCTTCTT $\begin{array}{lllllllllllllllll}I & K & R & A & V & N & I & P & F & K & V & H & L & R & C & K & A\end{array}$

151 ATAAAAAGAG CTGTGAACAT TCCTTTTAAA GTACATTTGC GGTGTAAAGC TATTTTTCTC GACACTTGTA AGGAAAATTT CATGTAAACG CCACATTTCG $\begin{array}{lll}A & F & C\end{array}$

201 CGCGTTCTGT TAAAACTGGA ATTGGAAGCT AATTGCTAAA TGTCTAACCA GCGCAAGACA ATTTTGACCT TAACCTTCGA TTAACGATTT ACAGATTGGT

251 AAAAAAAAAA AAAAAAAAAA AAAA TTTTTTTTTT TTTTTTTTTT TTTT 


\section{Figure 2}

(A)

$$
\begin{array}{ll}
\text { Kunitzin-RE } & \text { AAKIILNPKFRCKAAFC } \\
\text { Ranatuerin-2Ra } & \text { AAKLLLNPKFRCKAAFC } \\
& * * * \quad * * * * * * * * * * * *
\end{array}
$$

Kunitzin-OS AVNIPFKVHLRCKAAFC

Ranatuerin-2R AVNIPFKVKFRCKAAFC

(B)

$$
\text { N---- } \mathrm{P}_{4} \mathrm{P}_{3} \mathrm{P}_{2} \mathrm{P}_{1} \mathrm{P}_{1} \mathrm{P}_{2} \mathrm{P}_{3} \mathrm{P}_{4} \mathrm{C}^{---C}
$$

Kunitzin

SPI 1

BPTI

TFPI Domain 1

PLI

APPI
AAPH
TFPI Domain 3
HAI-2 Domain 1
UPTI
AsKC-1

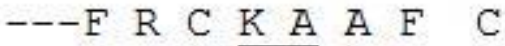

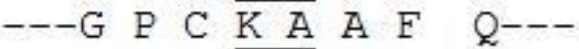

$---G \quad P \quad C \quad \overline{K ~ A}$ I $M \quad \mathrm{~K}---$

$--G \quad P \quad C \quad \overline{K ~ A}$ I $M \quad \mathrm{~K}---$

$---G$ P C $\overline{K A}$ R M I---

$---G$ P $C$ C R A M I I---

$---G \quad P \quad C \quad \bar{R}$ A $V$ M P---

$---G$ L $C \bar{R}$ A $N$ E N N---

$--G$ R C $\overline{R A}$ S M P---

-- G P C $\overline{R \text { A }}$ H F I---

$---G R C \overline{R A} S H \quad P---$ 
Figure 3

(A)

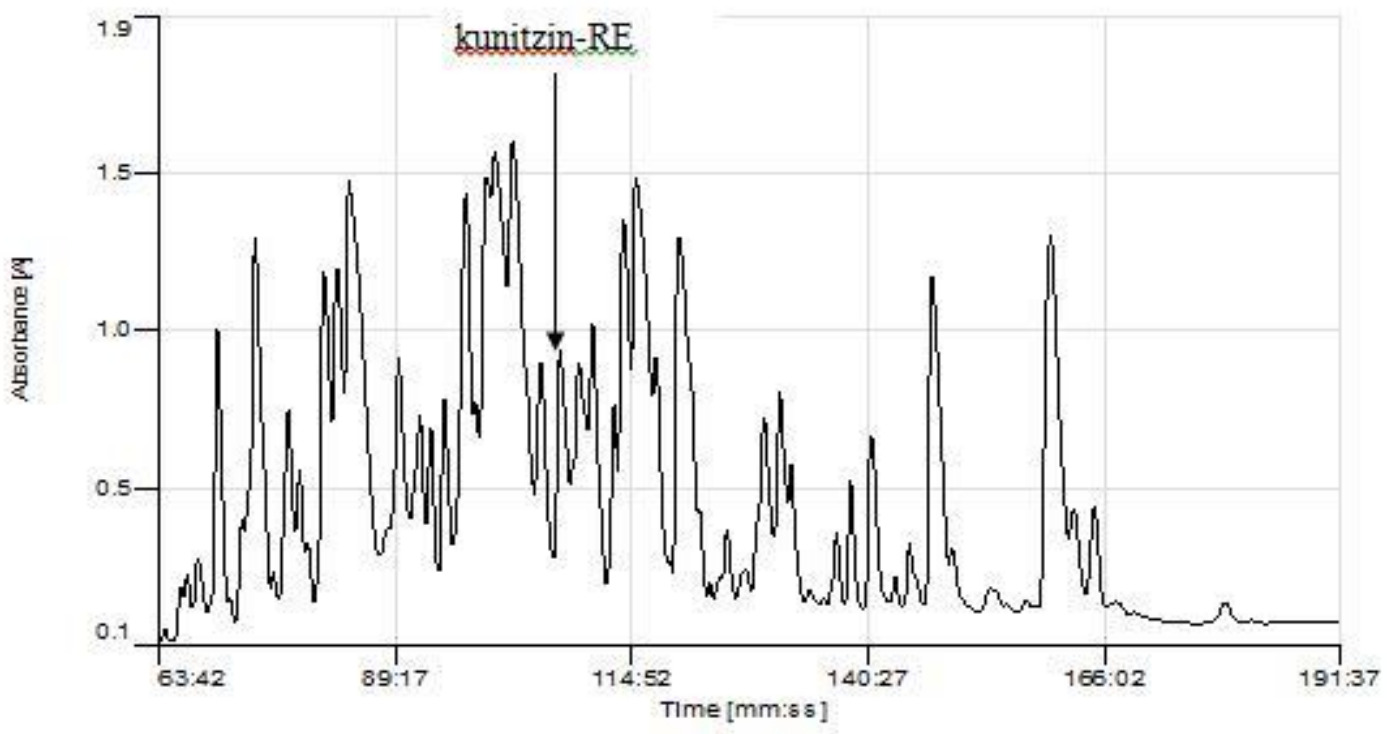

(B)

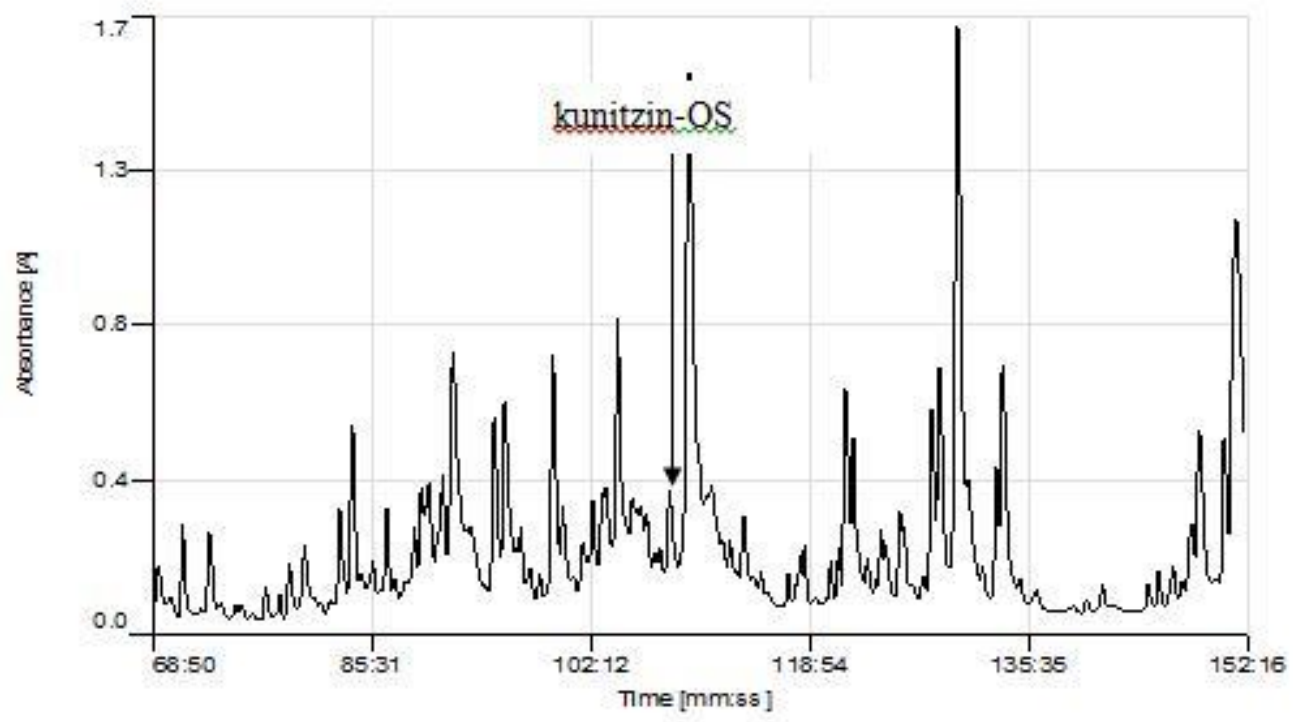




\section{Figure 4}

(A)

\begin{tabular}{|c|c|c|c|c|c|c|}
\hline$\# \mathbf{1}$ & $\mathbf{b}(\mathbf{1 +})$ & $\mathbf{b}(\mathbf{2 +})$ & $\mathbf{S e q}$ & $\mathbf{y}(\mathbf{1 +})$ & $\mathbf{y ( 2 + )}$ & $\mathbf{\# 2}$ \\
\hline 1 & 72.04440 & 36.52584 & $\mathrm{~A}$ & & & 17 \\
\hline 2 & 143.08152 & 72.04440 & $\mathrm{~A}$ & 1823.01836 & 912.01282 & 16 \\
\hline 3 & 271.17649 & 136.09188 & $\mathrm{~K}$ & 1751.98124 & 876.49426 & 15 \\
\hline 4 & 384.26056 & 192.63392 & $\mathrm{I}$ & 1623.88627 & 812.44677 & 14 \\
\hline 5 & 497.34463 & 249.17595 & $\mathrm{I}$ & 1510.80220 & 755.90474 & 13 \\
\hline 6 & 610.42870 & 305.71799 & $\mathrm{~L}$ & 1397.71813 & 699.36270 & 12 \\
\hline 7 & 724.47163 & 362.73945 & $\mathrm{~N}$ & 1284.63406 & 642.82067 & 11 \\
\hline 8 & 821.52440 & 411.26584 & $\mathrm{P}$ & 1170.59113 & 585.79920 & 10 \\
\hline 9 & 949.61937 & 475.31332 & $\mathrm{~K}$ & 1073.53836 & 537.27282 & 9 \\
\hline 10 & 1096.68779 & 548.84753 & $\mathrm{~F}$ & 945.44339 & 473.22533 & 8 \\
\hline 11 & 1252.78891 & 626.89809 & $\mathrm{R}$ & 798.37497 & 399.69112 & 7 \\
\hline 12 & 1355.79810 & 678.40269 & $\mathrm{C}$ & 642.27385 & 321.64056 & 6 \\
\hline 13 & 1483.89307 & 742.45017 & $\mathrm{~K}$ & 539.26466 & 270.13597 & 5 \\
\hline 14 & 1554.93019 & 777.96873 & $\mathrm{~A}$ & 411.16969 & 206.08848 & 4 \\
\hline 15 & 1625.96731 & 813.48729 & $\mathrm{~A}$ & 340.13257 & 170.56992 & 3 \\
\hline 16 & 1773.03573 & 887.02150 & $\mathrm{~F}$ & 269.09545 & 135.05136 & 2 \\
\hline 17 & & & $\mathrm{C}$ & 122.02703 & 61.51715 & 1 \\
\hline & & & & & & \\
\hline
\end{tabular}

(B)

\begin{tabular}{|c|c|c|c|c|c|c|}
\hline \#1 & $\mathbf{b ( 1 + )}$ & $\mathbf{b ( 2 + )}$ & Seq. & $\mathbf{y ( 1 + )}$ & $\mathbf{y ( 2 + )}$ & $\mathbf{\# 2}$ \\
\hline 1 & 72.04440 & 36.52584 & $\mathrm{~A}$ & & & 17 \\
\hline 2 & 171.11282 & 86.06005 & $\mathrm{~V}$ & 1845.99795 & 923.50261 & 16 \\
\hline 3 & 285.15575 & 143.08151 & $\mathrm{~N}$ & 1746.92953 & 873.96840 & 15 \\
\hline 4 & 398.23982 & 199.62355 & $\mathrm{I}$ & 1632.88660 & 816.94694 & 14 \\
\hline 5 & 495.29259 & 248.14993 & $\mathrm{P}$ & 1519.80253 & 760.40490 & 13 \\
\hline 6 & 642.36101 & 321.68414 & $\mathrm{~F}$ & 1422.74976 & 711.87852 & 12 \\
\hline 7 & 770.45598 & 385.73163 & $\mathrm{~K}$ & 1275.68134 & 638.34431 & 11 \\
\hline 8 & 869.52440 & 435.26584 & $\mathrm{~V}$ & 1147.58637 & 574.29682 & 10 \\
\hline 9 & 1006.58331 & 503.79529 & $\mathrm{H}$ & 1048.51795 & 524.76261 & 9 \\
\hline 10 & 1119.66738 & 560.33733 & $\mathrm{~L}$ & 911.45904 & 456.23316 & 8 \\
\hline 11 & 1275.76850 & 638.38789 & $\mathrm{R}$ & 798.37497 & 399.69112 & 7 \\
\hline 12 & 1378.77769 & 689.89248 & $\mathrm{C}$ & 642.27385 & 321.64056 & 6 \\
\hline 13 & 1506.87266 & 753.93997 & $\mathrm{~K}$ & 539.26466 & 270.13597 & 5 \\
\hline 14 & 1577.90978 & 789.45853 & $\mathrm{~A}$ & 411.16969 & 206.08848 & 4 \\
\hline 15 & 1648.94690 & 824.97709 & $\mathrm{~A}$ & 340.13257 & 170.56992 & 3 \\
\hline 16 & 1796.01532 & 898.51130 & $\mathrm{~F}$ & 269.09545 & 135.05136 & 2 \\
\hline 17 & & & $\mathrm{C}$ & 122.02703 & 61.51715 & 1 \\
\hline
\end{tabular}


Table 1

\begin{tabular}{|l|l|l|l|l|}
\hline Peptide & Fraction & Mr(obs) & Mr(calc) & Primary structure \\
\hline Kunitzin-RE & 104 & 1893.50 & 1894.39 & AAKIILNPKFRCKAAFC \\
\hline Kunitzin-OS & 100 & 1916.65 & 1917.38 & AVNIPFKVHLRCKAAFC \\
\hline
\end{tabular}

Table 2

\begin{tabular}{lll}
\hline Peptide & $\mathrm{Ki}(\mu \mathrm{M})($ trypsin$)$ & $\mathrm{Ki}(\mu \mathrm{M})$ (chymotrypsin) \\
\hline AAKIILNPKFRCKAAFC & 5.56 & N.I.* \\
AAKIILNPKFRCFAAFC & 48.37 & 17.5 \\
AVNIPFKVHLRCKAAFC & 7.56 & 329 \\
AVNIPFKVHLRCFAAFC & N.I.* & 67.98 \\
VHLRCKAAFC & 86.54 & N.I.* \\
CKAAFC & N.I.* & N.I.* \\
\hline
\end{tabular}

*No inhibition was observed using peptide concentrations up to and including $1 \mathrm{mM}$.

P1 positition is highlighted.

Table 3

\begin{tabular}{llll}
\hline Peptide & E.coli $(\mu \mathrm{M})$ & S.aureus $(\mu \mathrm{M})$ & Candida $(\mu \mathrm{M})$ \\
\hline AAKIILNPKFRCKAAFC & 30 & NA* $^{*}$ & NA* $^{*}$ \\
AAKIILNPKFRCFAAFC & 160 & NA* & NA* $^{*}$ \\
AVNIPFKVHLRCKAAFC & 20 & NA* & NA* $^{*}$ \\
AVNIPFKVHLRCFAAFC & NA* & NA* $^{*}$ & NA* $^{*}$ \\
VHLRCKAAFC & NA* $^{*}$ & NA* & NA* $^{*}$ \\
CKAAFC & NA* $^{*}$ & NA* & NA* \\
\hline
\end{tabular}

$\mathrm{NA}^{*}=$ not active using peptide concentrations up to and including $200 \mu \mathrm{M}$. 
Table 4

\begin{tabular}{|l|l|l|l|}
\hline Peptide & Sequence & $\operatorname{Mr}($ calc $)$ & $\operatorname{Mr}($ obs $)$ \\
\hline Kunitzin-RE 1-17 & AAKIILNPKFRCKAAFC & 1894.39 & 1894.85 \\
Kunitzin-RE 4-17 & IILNPKFRCKAAFC & 1624.06 & 1625.23 \\
Kunitzin-RE 1-11 & AAKIILNPKFR & 1270.58 & 1271.22 \\
Kunitzin-RE 1-9 & IILNPKFR & 1000.25 & 1000.67 \\
Kunitzin-RE 4-11 & AAKIILNPK & 967.21 & 968.05 \\
\hline \multicolumn{3}{|c|}{$\downarrow$ site means the cleavage position $^{\downarrow}$} \\
& AAK ${ }^{\downarrow}$ IILNPK $^{\downarrow}$ FR $^{\downarrow}$ CKAAFC \\
\hline
\end{tabular}

\begin{tabular}{|c|c|c|c|}
\hline Peptide & Sequence & $\operatorname{Mr}($ calc $)$ & $\operatorname{Mr}(\mathrm{obs})$ \\
\hline Kunitzin-OS 1-17 & AVNIPFKVHLRCKAAFC & 1917.38 & 1916.87 \\
\hline Kunitzin-OS 1-11 & AVNIPFKVHLR & 1293.57 & 1293.15 \\
\hline Kunitzin-OS 1-7 & AVNIPFK & 787.95 & 786.72 \\
\hline \multicolumn{4}{|c|}{$\downarrow$ site means the cleavage position } \\
\hline
\end{tabular}

